\title{
A critical look at Didache 1:4b and its reflection on the non-retaliation of the Nigerian church
}

\begin{tabular}{|c|c|}
\hline $\begin{array}{l}\text { Author: } \\
\text { Prince E. Pete }\end{array}$ & 2 (1) \\
\hline $\begin{array}{l}\text { Affiliation: } \\
\text { Department } \\
\text { Cultural Studi } \\
\text { Nigeria, Nsukk }\end{array}$ & $\begin{array}{l}\text { Religion and } \\
\text { s, University of } \\
\text { a, Nigeria }\end{array}$ \\
\hline $\begin{array}{l}{ }^{2} \text { Department c } \\
\text { Testament anc } \\
\text { Literature, Fac } \\
\text { and Religion, L } \\
\text { Pretoria, Preto }\end{array}$ & $\begin{array}{l}\text { f New } \\
\text { Related } \\
\text { ulty of Theology } \\
\text { Iniversity of } \\
\text { ria, South Africa }\end{array}$ \\
\hline $\begin{array}{l}\text { Research Proje } \\
\text { Project Leade } \\
\text { Project Numb }\end{array}$ & $\begin{array}{l}\text { ct Registration: } \\
\text { r: E. Van Eck } \\
\text { er: } 2400030\end{array}$ \\
\hline $\begin{array}{l}\text { Description: D } \\
\text { research assoc } \\
\text { Ernest van Eck } \\
\text { of New Testan } \\
\text { Related Litera } \\
\text { Theology and } \\
\text { University of P }\end{array}$ & $\begin{array}{l}\text { Peters is a } \\
\text { iate of Prof. Dr } \\
\text { Department } \\
\text { hent and } \\
\text { ture, Faculty of } \\
\text { Religion, } \\
\text { retoria. }\end{array}$ \\
\hline $\begin{array}{l}\text { Correspondin } \\
\text { Prince E. Peter } \\
\text { prince.peters. } \\
\text { edu.ng }\end{array}$ & $\begin{array}{l}\text { g author: } \\
\text { s, } \\
\text { 195254@unn. }\end{array}$ \\
\hline $\begin{array}{l}\text { Dates: } \\
\text { Received: } 01 \mathrm{~J} \\
\text { Accepted: } 24 \\
\text { Published: } 12\end{array}$ & $\begin{array}{l}\text { une } 2020 \\
\text { Aug. } 2020 \\
\text { Nov. } 2020\end{array}$ \\
\hline $\begin{array}{l}\text { How to cite th } \\
\text { Peters, E., } 202 \\
\text { look on Didad } \\
\text { reflection at th } \\
\text { retaliation of t } \\
\text { church', HTS T } \\
\text { Studies/Theolc } \\
\text { Studies 76(4), } \\
\text { https://doi.org } \\
\text { v76i4.6177 }\end{array}$ & $\begin{array}{l}\text { is article: } \\
0, \text { 'A critical } \\
\text { he } 1: 4 \mathrm{~b} \text { and its } \\
\text { ee non- } \\
\text { he Nigerian } \\
\text { eologiese } \\
\text { gical } \\
\text { a6177. } \\
\text { / } / 10.4102 / \text { hts. }\end{array}$ \\
\hline $\begin{array}{l}\text { Copyright: } \\
\text { () 2020. The A } \\
\text { Licensee: AOSI } \\
\text { is licensed und } \\
\text { Creative Comn } \\
\text { Attribution Lic }\end{array}$ & $\begin{array}{l}\text { uthors. } \\
\text { IS. This work } \\
\text { ler the } \\
\text { nons } \\
\text { ense. }\end{array}$ \\
\hline Read online & \\
\hline 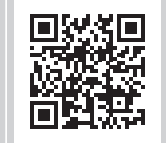 & $\begin{array}{l}\text { Scan this QR } \\
\text { code with your } \\
\text { smart phone or } \\
\text { mobile device } \\
\text { to read online. }\end{array}$ \\
\hline
\end{tabular}

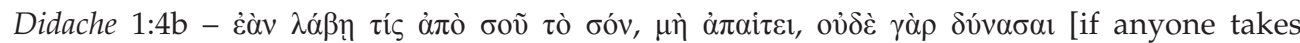
something from you that is yours, do not ask it back, because you should not or would not be able to] - is discussed in this article as problematic to the present mindset of the Nigerian church, especially as frontal attacks and premeditated persecutions from rival religions daily threaten to exterminate the Christian faith in Nigeria. This article argues that the Christians in Nigeria unwittingly interpreted this first-century document and wrongly so because this interpretation has metamorphosed into an ideology. The article suggests a sharp measure against this ideology.

Contribution: The church in Nigeria is controlled in their attitude towards self-defense by the text of Didache 1:4b. This article's contribution is a reexamination of the text in comparison to its parallel in the synoptic texts to assert that the synoptic texts, instead of Didache 1:4b, suggests non-violent self-defense.

Keywords: Didache; Church; Violence; Religion; Nigeria.

\section{Introduction}

The church ${ }^{1}$ is living in a period in which religious crisis and violent attacks of various kinds have become a daily occurrence. Some of the attacks, which assume international magnitude with no less consideration to onslaughts of smaller capacity, have religious intentions underlying them. ${ }^{2}$ World history cannot easily erase Al Qaeda's attack on America's World Trade Centre, New York, in 2001, forget the killings of innocent local and American Christians in Iran and Syria by ISIS, forget the deadly bombings and massacre of almost the entire populace of Nigeria's North-East by Boko Haram or forget the Fulani herdsmen invasion of Southern Nigeria, which is stil ongoing.

Other outrageous attacks that have badly affected Christians in their home countries have been reported several times. ${ }^{3}$ Recently, there have been reported cases on social media of various abuses on Christianity as a religion. The most trending is that of a woman who turned the holy Bible into a waste bin. There is also the alleged attempt by Netflix, an internationally renowned internet streaming service provider, to release a movie portraying Jesus as homosexual.

In Nigeria, 'violence based on religious affiliation and religious policies have indeed caused physical and psychological damage to several people thereby legitimising religious schism among Nigerians' (Oluwaseun 2016:23). It is also reported that (Joseph \& Rothfuss 2012):

$[E]$ ndemic religious intolerance, which has been the order of the day in northern Nigeria, and the struggle to reintroduce historic Islamic dominance in the region through the vehicle of religious extremism, are the twin drivers of Christian persecution in Nigeria. The daily experiences of Christians, who are marginalised and deprived of their citizens' rights in many parts of northern Nigeria, especially in the Sharia states, have been largely overshadowed by the frequent reports on sectarian violence by Boko Haram and 'clashes' between Muslims and Christians. (pp. 74-75)

1.The church represented in this article is the kind which corroborates Muller's work as the communion of believing saints, which the Holy Ghe thus gan Holy Ghost thus gather, coetus fidelium (see Mueller 1934:541). Augustine's assertion Some scholars have, however, discussed Augustine's asceticism of the church; an asceticism which would have given the church in Nigeria its non-retaliation colouration (see Grabau 2015:21-43; Heston 1840:502-512; Mersch 1933)

2.We cannot deny that religion has contributed in spreading hate and violence. Available statistics show that religion (especially prophetic religions) has been responsible for remote and immediate causes of some bloodbath in history especially since the medieval era in their efforts to missionise the whole world. For details on religion and war, see Gerlitz (1990) and Küng (1992, 2004:688-719).

3.It is reported that 'Christians around the Middle East have been subject to vicious murders' (Katulis, DeLeon \& Craig 2015:1). Also, 'Christians in Nigeria have been systematically persecuted for many years' (Ochab 2016:1), and in India, 'violence and harassment against Christians is extensive' (Kuhlin n.d.:19). 
Based on these happenings on the religious scene in Nigeria it is the view of this article that some persons and religious sects amongst prominent religions have arrogated upon themselves the power to monopolise violence in Nigeria. Their persistent assaults are probably because of little or no retaliation from the assaulted. Although the subtle aim of violent religious sects is to raise a religious kingdom on earth, they go about it quite violently where all mankind will either willingly submit to the cause or perish. ${ }^{4}$ In countries where they dominate, such religions enforce stringent measures aimed at bending the minority to their rule, and where they are the minority, they initiate very deceptive strategies, bidding their time for a full conquest at the slightest opportunity. ${ }^{5}$ The case is completely different in countries, like Nigeria, where these violent-prone religions stand on almost equal strength with each other in terms of population and economic power.

In such a situation attacks are more regular, especially when the religious groups involved in the struggle are also from different ethnic groups. ${ }^{6}$ This situation has raised global concern as the act has become a major challenge for world peace. ${ }^{7}$ Scholars and opinion leaders have made academic predictions about the marginalisation and privatisation of, or at its worse, the disappearance of religion and the subsequent enthronement of global secularism (see Riesebrodt 2014:1; Wright 1959:32-33). The reverse, however, seems to be the case right now in Africa, with religion growing by leaps and bounds, amassing a strong appetite to swallow liberalism and secularism.

Whilst it is common knowledge that no religion has the monopoly of violence most times through terrorism, ${ }^{8}$ there seems to be the giving up on religious violence by some

4.No religion is exempt from violence; however, the attacks and counter-attacks in religious settings in Nigeria are mainly between Islam and Christianity. This in fact exemplifies their constant struggle against each other amongst world religions. The al-jihad al-asghar [Lesser Jihad] has not allowed Muslims to pt wo religions. The al-jihad al-asghar [Lesser had] has not allowed Muslims to peacefully cohabit with the people of Christian faith in many countries of the world, and Nigeria in particular, more information on al-jihad al-asghar and al jihad al-muqaddas, see Firestone 1996 and Peters 1995).

5.Unlike Syria, Iran, Pakistan, Saudi Arabia and Egypt, where Muslims are the majority in number, their presence in the West is regulated with, sometimes, stringen measures to checkmate terrorism, which is presently (either rightly or wrongly) associated with Islam (see Dalhat 2015:273-282). Dalhat (2015:273) euphemistically referred to terrorist attacks experienced in the West as 'political tension'. The areas described as the 'West' loosely correspond to places erstwhile belonging to 'the Atlantic littoral of Europe': the British Isles, Scandinavia, the Low Countries, France and Iberia plus America (McNeill 1997:513-524). Christianity itself as one of the monotheistic religions shares the accusation of their inclination 'to use force' against other religions (Küng 2005:253).

6.Nigeria's multiple ethnicities would have been a great advantage for it both politically and economically if harnessed. There is, however, a complete refusal to maximise its ethnic diversity (see Ngele \& Peters 2019:5).

7.Nigeria is a good example of the case cited here, and international organisations recognise religion as a major cause of conflict in that country. A 2012-2014 UN report stated that 'with ethnic groups being subsumed under a larger religious political identity of a Muslim North or a Christian South or in other instances, of religion standing relatively alone as a driver of conflicts ... religion is clearly now a growing divide over which the unity of the nation is increasingly stretched' (see Cox Orsborn \& Sisk 2012-2014 UN report)

8.Juergensmeyer (2001:357) observed that in regard to religious extremism and violence, 'Osama bin Laden is no more representative of Islam than Timothy McVeigh is of Christianity, or Japan's Shoko Asahara is of Buddhism'. Terrorism thus is clearly not limited to the Arabs or Muslims, but embraces all religions (see also Hudson 1999:82; Yin 2013:59). McVeigh's hatred of the government and spreading of anti-government literature because of government's role in the destruction of of anti-government literature because of government's role in the destruction of called Branch Davidians, does not portray his terrorist attack as religious or called Branch Davidians, does not portray his terrorist attack as religious or a
defence of a branch of Christianity. It conveyed rather the acts of one who defence of a branch of Christianity. It conveyed rather the acts of
'possessed a very anti-government sentiment' (Gilbert-Bonner 2016:3). religions and reverting to preaching peace and love even after multiple provocations and attacks; Christianity in Nigeria falls into this category. Brown (2019:2) suggested that the 'New Testament text, church tradition and cultural mores converge in establishing non-violence as the preeminent mark of those who would be faithful followers of Christ'. Although it is not clear from Brown (2019) on how the New Testament (NT) text contributed to the non-violent, non-retaliatory position of the church today, the Christian church in Nigeria is, however, reminded that:

$[I] \mathrm{n}$ a context where violence is embedded in the social order, the ethos of non-violence as an end goal in itself generally fails to aid the Christian, particularly the Black Christian, in the task of honouring one's dignity and the dignity of one's neighbour. (p. iii)

It seems that Christianity in Nigeria lives by Volf's (2002:5) 'thick' faith method. ${ }^{9}$ Little wonder it has pursued peace to the point of being the persecuted (Joseph \& Rothfuss 2012:78). Such persecutions have grown at an alarming rate in Nigeria, with the 'endemic religious intolerance, which has been the order of the day' (Joseph \& Rothfuss 2012:74). This has necessitated a search into the possible cause of Christianity's non-retaliatory policy.

If Nigerian Christians have opted for prayer instead of defending themselves in the face of annihilation, then they were strongly indoctrinated. Such indoctrination (as earlier insinuated) may not have their root in the New Testament text because it was never the focus of Jesus' praxis and teaching (see Horsley 1986:24; Weaver 1992:35). Reid (2006) is one of the scholars who believe that certain portions of the NT text supports non-violence; however, she points out that there are eight parables that talk about God as a violent being, viz:

[T] he Weeds and the Wheat (13:40-43), the Dragnet (13:47-50), Forgiveness Aborted (18:23-35), the Final Judgment (25:31-46) ... Treacherous Tenants (21:33-46), the Wedding Feast (22:1-14), Faithful Servants (24:45-51), and the Talents (25:14-30). (p. 31)

This, Reid argues, puts Christians in a dilemma. To resolve the dilemma, she sets out seven possible solutions of which the second reads as follows: 'A reading of Jesus as advocating active, nonviolent resistance to evil could be an anachronistic reading' (Reid 2006:32). This point of view is adopted in this study. ${ }^{10}$ Therefore, we turn our faces to other sources of Christian catechetical information, whose base is heavy in weight especially those that were prominent within the early church era. The Didache proved effective in the search because it was found with statements whose interpretation could actually be responsible for the non-retaliatory ideology. Therefore, the study critically examines its context and also the present effect of its content as passed down traditionally.

9.Volf $(2002: 2)$ coined the phrase thin and thick Christian faith. He was of the opinion that "thin" Christian faith may potentially lead to violence, "thick" Christian faith actually serves to create and sustain a culture of peace'.

10.To corroborate Reid's argument, Brown (2019:2) argues that the gospel, especially Jesus' Sermon on the Mount, is a pivotal text in forming the theology of nonviolence. Klassen (1992:9) also discussed what he called 'enemy love' as foundational in Jesus and contained in the gospels. He believed that 'Luke and Matthew appear to be drawing from a common source that included at least the "words": [agapatetous echthrous hymon] "Love your enemies"'. 
Fahey's (2018:7-21) Four Traditions on War and Peace serves as a framework for the article's experimental research design.

\section{Abrahamic or theistic religions and violence}

There are certain eastern religions whose antecedents are basically repository of revelation knowledge from the loins of Abraham. Three religions fit this description, namely Judaism, Christianity and Islam. ${ }^{11}$

The history of the Abrahamic religions, when considered as parallel religions, arose from an oscillation between the two poles of an ellipse: one God with two sets of instructions; that of nature and grace (Peachey 1997:11). By 'nature' and 'grace', it is meant that the first call of Abraham to be born in a certain geographical location with familial allegiance (his father's house) is contrasted with the next new call (grace), which entailed that he had to go to a land which God shall have shown him. This call of grace that contained the blueprint to form a new nation by Abraham is considered by Peachey (1997:11) as 'a new particularity (which) embodies and constitutes a new universality'. However universal the call turned out to be, it yielded to its modus operandi by producing multiple faiths whose only unity of purpose and centralised dogma is the senseless killings of brother religions; killings that Judge calls 'fundamental dependence on human sacrifice' (Judge 2018). 'Human sacrifice' may be the most suitable term for the various religious massacres experienced amongst these Abrahamic religions because there are little objectives for the killings besides the advancement of religion. ${ }^{12}$

In Nigeria, the three religions referred here as Abrahamic religions are represented, with Christianity and Islam taking the lead. Their presence in the country is not without their various inherent conflicts and violence, which has made Nigeria 'one of the world's major laboratories for the study of religious-based conflict and reconciliation' (Vaughan 2016:1). Christianity and Islam came onto the Nigerian religious scene to displace African Traditional Religions because of their various appeals to Nigerians as more civilised religions. Such civilisation was however mired by the missionaries' 'hypocrisy'

11. Bahá'i faith is not included in Abrahamic religions in this article because of the confusion of what the religion really represents. A brief look at Bahá'í faith historically is necessary to corroborate this assertion. After a Shi' 1 Muslim called Mirza Sayyid All Shirazi started the movement which was late consoliday by Mirza Husayn Ali Nuri, the religion (formed from the Islamic background) was found to lack the precise defintion in doctrine and theology. For example, Nuri who was also called Bahá'u'lláh was so many things to so many religions of the world all at once. He was 'fifth incarnation of Buddha, reincarnation of Krishna, Messiah for Jews, and returned Christ for Christians' (Ančić 2014:3). One then wonders what exactly he was to Bahá'í faith. Presently, Bahá'í faith seems to be a mixture of Christian and Moslem esotericisms with strange mix-up in doctrinal statements. Lee (2011:190) said that Baha'is do not regard Jesus Christ as the incarnation of the Godhead. However, he is not merely human either. He is recognised as a 'Manifestation of God' (a sort of intermediate category), as are Abraham, Moses, Muhammad, Buddha and other founders of world religions (see Cole 1982:1-38; Effendi n.d.:99-119).

12.Volf (2002:3) considered the violence that currently happens on global scale since those that plagued Europe from the 1560 s to the 1650 s as mainly religious motivated. Brubaker (2015:4), to the contrary, argues that conflicts 'involving religiously identified parties or claimants need not involve religiously defined stakes'. He further is of the opinion that 'there may be conflicts over political stakes'. He further is of the opinion that 'there may be conflicts over political
power, economic resources, symbolic recognition, cultural reproduction or national self-determination' (Brubaker 2015:4)
(Adamo 2011:285), specifically Christian missionaries. This then produced or encouraged syncretism. On the part of Islamic faith in Nigeria one expected that they would have salvaged the religious and spiritual life of Nigerians because hypocritical religiosity found amongst Christians was not exactly their weakness; however, they failed in this duty when certain terrorist groups arose out of the religion to apply a dangerous method of proselytism, a very strange method of advancing religious faith, which has been frowned upon by Nigerians and whose after-effects far outweigh the civilisation the religion intends to establish. Originally, Islam found its footing in Northern Nigeria by the use of Jihad and Lesser Jihad. Vaughan (2016:2) observed that 'the Sokoto Jihad of 1804-1808 transformed not only the Hausa city-states, but also shaped the geopolitics of their neighbors to the south'.

However, after these wars and peaceful settlements of all tribes in Nigeria, one does not expect any form of religious terrorism in Nigeria, but the reverse seems to be the case. ${ }^{13}$ Presently it seems that the religious battle in Nigeria is between the northern dominated Islam and the southern dominated Christianity (Afolabi 2015:46, 2016:26), and an untold number of lives and properties have been wasted with the most targeted victims being the Christians. ${ }^{14}$ Looking at the extent of damages and threat to life experienced by Christians in Nigeria, it arouses the question: 'Why do Christians resort to non-self-defence in the face of such annihilation?' The only force strong enough to put them in the shackles of non-self-defence from religious attacks must be religion itself. First of all, the fanatics that take violence as their forte and a stock in trade do so not because the religion behind which they hide is in itself violence prone, but because they resorted to self-exegesis (gagging of their holy text and faulty hermeneutics that naturally follow). The same thing applies to the Christian religion. When they are reluctant to defend themselves robustly and instead resort to prayer, they are also controlled by their own religious text. Using Matthew 5:38-42, for example, the kind of demands that Jesus made of his followers in that text, and considering that 'any hint that could explain these demands as prudent and reasonable is missing' (Luz 2007:307), it presents the text 'as one of the hard sayings of Jesus' (Cruise 2018:83). The difficulty in accepting such demands in the Nigerian situation was the reason why Ige (2016:29) concluded that it 'worked out in Jesus, perhaps, for Jesus and his days alone when civilization was still in the embryo'. But then, within the gospels, it seems that the commands by Jesus towards a non-retaliating action in the face of annihilation do not include inability to defend oneself as projected in Didache.

\footnotetext{
13.Sulaiman gives a brief chronicle of the toll religious crisis has taken on the country 'Some of the prominent examples include those of the Kasuwan Magani in 1980 Zango Kataf and Gure-Kahugu in 1987, Kafanchan and Lere in 1987, Ilorin and Jerein 1989, Tafawa Balewa in 1991 as well as that of Zango Kataf in 1992' (see also Eniola 2010:77-81; Sulaiman 2016:86; Teehan 2010:145-147). The category of conflicts exists mostly in the Northern part of the country where the main protagonists are Hausa and Fulani Muslims and Christian ethnic minorities. The 'pagan question' it has been argued seems to play a major role in creating a climate of suspicion and intolerance amongst the groups (Eniola 2010:77-81; Sulaiman 2015:111-120).

14.Stonawski et al. (2016:3) told of the slaughter of thousands of people in Kaduna alone when Sharia law was introduced. They also recall the attacks on Christians and moderate Muslims by Boko Haram as 'part of efforts to establish an Islamic caliphate'.
} 
An exegesis of Matthew 5:38-42 will provide answers to this. Barne's commentary:

[C]hrist did not intend to teach that we are to see our families murdered, or be murdered ourselves; rather than to make resistance. The law of nature, and all laws, human and divine, justify self-defense when life is in danger. It cannot surely be the intention to teach that a father should sit by coolly and see his family butchered by savages, and not be allowed to defend them. Neither natural nor revealed religion ever did, or ever can, inculcate this doctrine. ${ }^{15}$ (n.p.)

\section{But when we remember:}

[T]hat our Lord Himself, when smitten by the servant of the high priest, protested, though He did not resist (Jn 18:22-23), and that St. Paul, under like outrage, was vehement in his rebuke (Ac 23:3). ${ }^{16}$ (n.p.)

we are forced to look deeper into the meaning of $\mu \grave{\eta} \alpha \dot{\nu} \tau \iota \sigma \tau \tilde{\eta} v \alpha \iota$ 'do not resist' in Matthew 5:39. We could argue that:

[T] he phrase translated as 'resist not evil/the evil one' sets the context for the next three verses. All are a comparison with a different type of 'evil one'. The verb can mean 'to stand against' and 'to set against', but the word also means 'to match with' and 'to compare'. It is unlike to mean 'resist' because the word requires and [sic] object but there is no object here. The 'evil/evil one' is in the form that requires a preposition in English, here, it would be 'with' as in 'compare with'. As we will see in subsequent verses, the idea is clearly not 'evil' but 'worthless'. This is of comparison much more sense in the context of the previous verse, Matthew 5:38, which was a comparison of forms of equity. ${ }^{17}$ (n.p.)

But we will definitely argue that, by its etymology, $\alpha v \theta i ́ \sigma \tau \mu$ means, to take a complete stand against someone or something, and this conveys the idea of opposition (Vine 1996:528) than defence. We can then aver that Jesus warns against opposing one's adversary. He never said anything about defence. Alternatively, we may join Davies and Allison (1988:541) to refer to the passage as hyperbolic. In that circumstance, such unwillingness of the Christian church in Nigeria to defend itself may not be predicated on the interpretation of the words of Jesus in the gospels. Koplitz (2018:16) on the other hand insisted that although the passage does not encourage violence, it nonetheless asks for justice. In short, the '... Bible contains conflicting views on violence that cannot be systematised into a clearly uniform "biblical view"' (Nel 2018:423). Jesus made several warnings to his Jewish disciples on possible attacks from their Jewish brethren. He told them in Matthew 10:17-21 that the culmination of such attacks would be to take them to court before Gentiles (nations other than Jews who presided over the political terrain of Israel at the time), and even to death. Jesus advised them to run (a form of defence) when they have the opportunity, if possible, from one Jewish city to another (Mt 10:23). In all the passages where Jesus spoke about persecution he never presented his immediate or future followers as unable to fight back or his

15.See https://biblehub.com/commentaries/barnes/matthew/5.htm.

16.See https://biblehub.com/commentaries/ellicott/matthew/5.htm.

17.See https://christswords.com/content/mat-539-do-not-resist-evil.
Way being the way of weakness, rather he proposed wilful yielding to persecution and non-retaliation. Once the logion of Matthew 10:23 was referred to, the problems inherent in its second part became manifest, which is that it is a text that is very problematic to interpret because of few complications, which the text presents. For example, how does an exegete

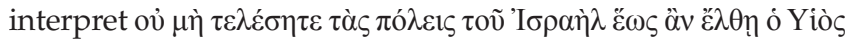

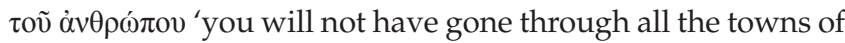
Israel before the Son of man comes?' The easiest way to handle the problem is to tow the path of the currently accepted perspective, which is to simplify its translation by giving it a smooth rendering. This is what is done in some English versions, translations that, however, create more problems than it solves. Giblin, for example, argues that the 'currently accepted perspective' of interpreting the text is 'well exemplified by a mistranslation ... in The New English Bible'. ${ }^{18}$ The New English Bible translation reads 'before you have gone through all the towns of Israel the Son of Man will have come'. The translation contradicts and radically changes the meaning of the text in the original Greek. Whilst it places the strength of its prediction on Christ's return, it downplays and alters the subjunctive $\tau \varepsilon \lambda \dot{\varepsilon} \sigma \eta \tau \varepsilon$, which appears in the aorist and which emphasises the completion of the missional assignment as complementary of Christ's return. This is justified by the presence of the conjunction $\tilde{\varepsilon} \omega \varsigma$, which normally goes with òv, explaining that of a truth, namely that the return is only delayed until the mission is accomplished. In addition, such translation fails to consider the emphatic negation, ov̉ $\mu$ ทे. To make the problem created more visible and to then validate the solution accorded it, Giblin (1967:638) gave a corroborative illustration 'Now compare the differences between the following examples: "Before you finish the book, I will have come," and "You will not finish the book until I come"".

Just like Matthew 5:39, it can be said that Christ's prediction in Matthew 10:17-21 did not encourage or motivate any kind of inability for Christians to defend themselves. In fact, the persecution Christ predicted is intramural ${ }^{19}$ and does not justify lack of self-defence in the face of annihilation from rival religion or religious sect.

\section{Didache: A study}

The text of the Didache has been aptly described as 'an intriguing dilemma ... that begs for interpretation and elucidation' (Jefford 2015:1). Its title describes a multiple form of usage, which has various theological meanings and

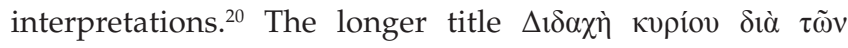

18.Moule (1966) is one of the scholars who went to great lengths to explain the complexities in the text of Matthew 10:23b. Giblin (1967:637) had referred to all the possible interpretations assembled by Moule as 'clock-and-calendar outlook', arguing that Moule's assemblage regulated Christ's return based on chronological time and space.

19.Richard Horsley's (1986:23) interpretation of Éx $\theta$ pò squabbles or enmity. He rejected the idea of 'foreign enemies' or even outsiders as referents (Klassen 1992:11).

20.Draper (1983:11) listed various titles based on various traditions and manuscripts:

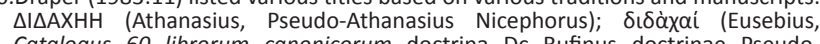
Catalogus 60 librorum canonicorum doctrina Dc Rufinus doctrinae Pseudo-

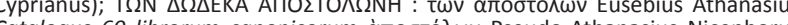
Catalogus 60 librorum canonicorum arootó $\lambda \omega v$ Pseudo-Athanasius Nicephorus

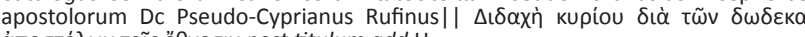

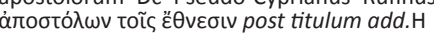




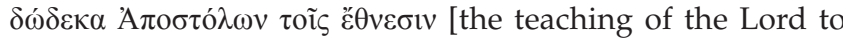
the nations, transmitted through the 12 apostles] projects a (Thomas 2019):

[W]ork conceived against the background of Mt. 28:18-20, professing to give the content of that which the twelve apostles taught to the 'Gentiles' or 'Nations' by the command of the Lord Jesus. It may therefore stand in a tradition somewhat different from the one that sees Paul as the Apostle to the Gentiles and the Twelve as missionaries to the Jews. (p. 1)

Giet (1970:39-170) was most probably correct in describing the Didache as enigmatic. For the purpose of this article, the enigmatic nature of the Didache is understood in the opulent display of its ability to weave ancient knowledge incorporated in Qumran tradition with sayings in Quelle. ${ }^{21}$

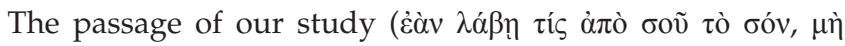

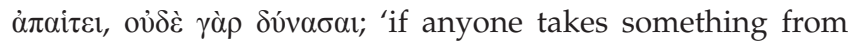
you that is yours, do not ask it back, because you should not (or would not be able to)' exemplifies this. Draper (1983) made a concrete opinion when he quoted Mees as having said that:

Mt 5:42 represents an anticlimax, whereas Did., provides a

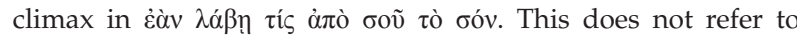
almsgiving as in Mt. but to the total confiscation of property facing a Christian for his faith. (p. 42)

By this, one realises that the deponent verb and its preceding

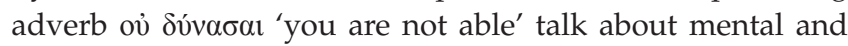
physical deprivation, which does not portray weakness that comes from moral obligation but weakness consequent on emasculation, subjugation, servitude and slave mentality. The Didache's pacific tendency to the extent of refusing bloodletting despite any cause was not in fact the command of Jesus or the original gospel redacted from the $Q$, but an adopted idea from one of the Qumran communities, the Yahad, a community badly abused mentally and physically amongst the Qumran sect (Fahey 2018:8). One example to corroborate this idea would suffice. Community Rule ${ }^{22}$ (1QS) 9:22 reads as follow: 'He shall leave to them wealth and earnings like a slave to his lord and like a poor man to his master'. According to the Habakkuk Commentary (1Qp Hab 8.8-12.10), the persecutor was nicknamed 'the Wicked Priest', 'who may have been the high priest Jonathan' (Fitzmyer 2019).

The pollution of the Christians' mentality by the incorporation of such idea contained in the Didache [teaching] into early Christian catechesis ${ }^{23}$ necessitated the belief that 'the true Christian portrayed in the "Teaching" could use no force himself; nor even if injured ought he to have recourse to

21.Scholars like Jefford (1989) and Tuckett (1996) have argued that the Didache have dependence on one or two of the synoptic gospels or the communities from where they were created, whereas others like Draper (1996), Kloppenborg (1979), Milavec (2003) and Rordorf (1991) have called the gospels' dependence of Didache into question. Here, this study suggests a pre-gospel date for the Didache and advocates that the Didache was furnished with materials such as the $\mathrm{Q}$ and the Qumran documents in its composition.

22.The Community Rule (S) includes the manuscripts of $1 Q S$ and $4 Q S a-j$, used by the Yahad and related sectarian communities to organise and regulate their communities (see Pula 2015:8)

23.0'Loughlin (2011:78) described Didache as 'less than a teaching document and (more of a) "church order" or "manual of discipline". pagan tribunals' (Spence 1888:10). As a first-century catechetical document, Didache was used to mould the mind frame of the early church and like $Q$, it has survived in various Christian traditions because the document unwittingly modified both the canonised scriptures, apostolic teachings, teachings of church fathers, ecumenical councils and to an extent even the canon law. Inclusively Didache 1:4b of the same document commanded strict non-retaliation to attacks (Draper 2011:5).

\section{Nigerian Christianity and misapplication of irenics}

Fahey (2018:7) recognised four approaches to war and peace: 'Pacifism, Just War, Total War and World Community'. Nigeria's pluralistic nature has made it a balkanised state in all ramifications, especially on the political front (Isomkwo \& Njor 2019:236). Hence, any effort to apply pacifism, which Fahey (2018:7) described as 'a personal and social philosophy that seeks the conversion of enemies through love and active nonviolence', would result in loss of both human and material resources especially on the part of those who apply it. That was why Ige (2016:32) insist that the pacific 'position is too simplistic to be a practical solution to the problem of the Christian and war'. It is no gainsaying the fact that pacifism (both absolute and selective), which is primarily communicated to Christianity through Didache 1:4b, has robustly produced huge human and material losses.

That Christianity especially in Northern Nigeria faces extermination ${ }^{24}$, whilst 'the government feeds the public and international community with misleading narratives and explanations for the terror' (Para-Mallam 2019:2), is a welldiscussed issue amongst scholars and researchers (Yake 2015:190). Assuming just war theory is adopted by the church in Nigeria to stop this extermination, are there biblical texts and patristic writings strong enough to defend the church from the accusation of the evils of war? Augustine's just war assertion begs for strong consideration. He asks (Augustine 1887):

[W] hat is the evil in War? Is it the death of some who will soon die in any case, that others may live in peaceful subjection? This is mere cowardly dislike, not any religious feeling. The real evils in war are love of violence (nocendi cupiditas), revengeful cruelty (ulciscendicrudelitas), fierce and implacable enmity, wild resistance, and the lust of power (libido dominandi) and such like. (p. 301)

For Augustine, war is justifiable only when it is undertaken by good men towards enshrining good conducts in humanity (Contra Faustum xxii:74). His belief in the evil of war is rather expressible in the inherent evil possessing the man of violence, which ultimately needs to be curbed. In his words (Augustine 1953):

$[H]$ e whose freedom to do wrong is taken away suffers a useful form of restraint, since nothing is more unfortunate than the

24.There are media reports of how those who convert to Christianity from Islam in Zamfara, Northern Nigeria, are sought with the sentence of death hanging over them (Jacob 2014:8). 
good fortune of sinners, who grow bold by not being punisheda penalty in itself- and whose evil will is strengthened by the enemy within. (p. 4)

One can only agree with Augustine when his words are applied in the Nigerian context where some terrorists hide behind religion to waste lives and resources of innocent Nigerians and such Nigerians are not willing to defend themselves. This is the after-effect of the teaching of pacifism, with its foundation in Didache $1: 4 \mathrm{~b}^{25}$ and its influence in the synoptic gospels. This pacifism, although somewhat fading within congregants in Nigerian Christianity, is still fully operational amongst the clergy.

Like Augustine, Ambrose was another Church Father who although hated war justified it when it 'preserves one's country from the barbarians or at home defends the weak or comrades' (De Officiis xxvii:129). This is obviously a position the Nigerian church has lost.

Finally, the Sitz-im-Leben of Luke 22:36 give Augustine and Ambrose's assertions the effrontery they deserve. Despite the difficulty $^{26}$ in carrying out exegesis on the text and its pericope, it should be stated that the text is not and cannot be interpreted as a call to war.

Rather it is in its totality a call to self-defence, which is what Just war 'theory' represents. The Expositor's Greek Testament puts forth that $\dot{\alpha} \lambda \lambda \grave{\alpha}$ võv 'but now' suggests 'an emphatic contrast between past and present or near future', a word pointing to the need for immediate action ${ }^{27}$. Cambridge Bible for Schools and Colleges asserts that 'It was to warn them of days of hatred and opposition in which self-defence might become a daily necessity ${ }^{28}$. The aorist imperative $\alpha \rho \alpha ́ \tau \omega$ 'let him take it' (a purse that equips him to buy whatever is necessary for his personal security on the mission), a mission, unlike the previous mission, introduces him to hostile persons and persecutors. 'He is going now not on a peaceful mission in connection with which he may expect friendly reception and hospitality, but on a campaign in an enemy's country' (Expository Greek Testament online [EGT]). With what is happening in Nigeria now, one wonders if Nigerians who are Christians are not already on a campaign in an enemy's country. The need to acquire a sword becomes so imminent that Jesus asks His disciples to sell off their upper

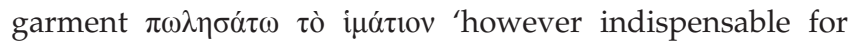
clothing by day and by night' (EGT online) and use the money instead to buy amongst other things, a sword. This does not place Jesus both on retaliatory and non-retaliatory seats, but on a single seat of self-defence.

25.The dangerous effect of Didache 1:4 $\mathrm{b}$ in the first century is documented in history MacGregor (2008:16) told us that 'from the close of the New Testament era until 174 C.E., no Christians served in the military or assumed government offices' (see also Hershberger 1944:57-59). This mentality has since persevered in Nigeria.

26. Moore (2009:2) listed the following scholars who agreed on the difficulty in understanding the text: 'Die Aufforderung, einSchwertzukaufen, istschwierigzuverstehen' (Mineshige); 'Der Zusammenhangbleibtdunkel' (Ernst), 'S'ilest un texteénigmatiquedansl'Evangile de Luc, c'estbiencelui-ci' (Meynet).

27.See https://biblehub.com/commentaries/egt/luke/22.htm.

28. See https://biblehub.com/commentaries/cambridge/luke/22.htm.

\section{Conclusion}

The study was about presenting the problem of nonretaliation by Nigerian Christians and that led to a search to the cause and effect by using form critical method, exegesis and experimental research design. The cause was found in the interpretation given to Didache $1: 4 \mathrm{~b}$ as a means of encouraging and indoctrinating the church in Nigeria by using the tool of pacifism, and the effect was the docility of the church and its inability to defend itself in the face of extermination and annihilation. The article suggested a proactive measure in the defence of Christians' lives and property in Nigeria by asking that the principle of selfdefence be adopted.

\section{Acknowledgements Competing interests}

The author declares that he has no financial or personal relationships that may have inappropriately influenced him in writing this research article.

\section{Author's contribution}

P.E.P. is the sole author of this research article.

\section{Ethical considerations}

This article followed all ethical standards for research without direct contact with human or animal subjects.

\section{Funding information}

This research received no specific grant from any funding agency in the public, commercial or not-for-profit sectors.

\section{Data availability}

Data sharing is not applicable to this article as no new data were created or analysed in this study.

\section{Disclaimer}

The views and opinions expressed in this article are those of the author and do not necessarily reflect the official policy or position of any affiliated agency of the author.

\section{References}

Adamo, D.T., 2011, 'Christianity and the African traditional religion(s): The postcolonia round of engagement', Verbum et Ecclesia 32(1), Art. \#285, 10 pages. https://doi. org/10.4102/ve.v32i1.285

Afolabi, O.O., 2015, 'The role of religion in Nigerian politics and its sustainability for political development', Net Journal of Social Sciences 3(2), 42-49.

Afolabi, O.O., 2016, 'Religious violence and national security in Nigeria, 1999-2011', International Affairs and Global Strategy 42, 23-31.

Ančić, B., 2014, Bahá'í Religion as a new religious movement?, viewed 18 December 2019, from https://www.researchgate.net/publication/265685750_Baha\%27i_ Religion_as_a_New_Religious_Movement.

Augustine, St., 1887, 'Contra Faustum Manichaeum', transl. R. Stathert, in P. Schaff (ed.), The Nicene and post-Nicene Fathers, vol. IV, pp. 151-365, Christian Literature, Buffalo, NY.

Augustine, St., 1953, Letters, vol. 3, transl. Sr. W. Parsons, S.N.D. Fathers of the Church, New York, NY. 
Brown, A.A., 2019, 'The violence of Jesus and the Justice of God', PhD dissertation, Faculty of Theology, Stellenbosch University, Stellenbosch.

Brubaker, R., 2015, 'Religious dimensions of political conflict and violence', American Sociological Association 33(1), 1-19. https://doi.org/10.1177/0735275115572153

Cole, J.R.I., 1982, 'The concept of manifestation in the Bahá'í Writings', in Bahá' Studies, Monograph 9, viewed 18 December 2019, from http://www-personal. umich.edu/ jrcole/bhmanif.htm.

Cox, F.D., Orsborn, C.R. \& Sisk, T.D., 2014, Religion, peace building, and social cohesion in conflict-affected countries, Sié Chéou Kang Center for International Security and Diplomacy, University of Denver, Colorado, CA.

Cruise, C., 2018, 'A methodology for detecting and mitigating hyperbole in Matthew 5:38-42', Journal of the Evangelical Theological Society 61(1), 83-103.

Dalhat, Y., 2015, 'Islam and the problem of social integration in the West', International Journal of Education and Research 3(7), 273-282.

Davies, W.D. \& Allison Jr. \& Dale, C., 1988, A critical and exegetical commentary on the Gospel according to Matthew, 3 vols., International Critical Commentary, T\&T Clark, Edinburgh.

Draper, J.A., 1983, A commentary on the Didache in the light of the Dead Sea scrolls and related documents, Tyndale House, Cambridge.

Draper, J.A., 1996, 'The Jesus tradition in the Didache', in J.A. Draper (ed.), The Didache in modern research, pp. 72-91, E.J. Brill, Leiden.

Draper, J., 2011, 'The moral economy of the Didache', HTS Teologiese Studies/ Theological Studies 67(1), Art. \#907, 10 pages. https://doi.org/10.4102/hts. v67i1.907

Efendi, S., 2006, The World Order of Bahá'u'lláh, viewed 20th October 2020, from http://www.gutenberg.org/ebooks/19298/19298-pdf.pdf.

Eniola, S.O., 2010, 'Reflections of religious violence in Nigeria', in A. Kunle (eds.), Introduction to peace and conflict studies: The Nigeria perspectives, pp. 77-81, University of Ado-Ekiti Press, Ado-Ekiti.

Fahey, J.J., 2018, 'An overview of four traditions on war and peace in Christian history', The Journal of Social Encounters 2(1), 7-21.

Firestone, R., 1996, 'Conceptions of holy war in Biblical and Qur'anic tradition', The Journal of Religious Ethics 24(1), 99-123.

Fitzmyer, J.A., 2019, Qumran community, New Catholic Encyclopaedia, viewed 28 December 2019, from https://www.encyclopedia.com/religion/encyclopediasalmanacs-transcripts-and-maps/qumran-community.

Gerlitz, P., 1990, 'Krieg I (Religionsgeschichtlich)', Theologische Realenzyklopädie 20 11-19.

Giblin, C.H., 1967, 'Theological perspective and Matthew 10:23b', Theological Studies 29(4), 637-661

Giet, S., 1970, L'enigme de la Didache, PFLUS 149 Ophrys, Paris.

Gilbert-Bonner, P., 2016, Terrorism: Timothy McVeigh and the Oklahoma City Bombing, ED 601: Statutory, Legal, and Regulatory Basis of Defense Security, Arlington, VA.

Grabau, J., 2015, 'On Christian asceticism, spiritual exercises in Saint Augustine's Confessions', Studies in Spirituality 25(1), 21-43.

Hershberger, G.F., 1944, War, peace, and nonresistance, Herald Press, Scottdale, PA.

Heston, E., 1840, 'The dogmatic preaching of the Fathers', Ecc. Rev., CIII.

Horsley, R.A., 1986, "Ethics and exegesis: "Love your enemies" and the doctrine of non-violence', Journal of the American Academy of Religion 54(1), 3-31.

Hudson, R.A., 1999, The sociology and psychology of terrorism: Who becomes a terroris and why?, Federal Research Division Library of Congress, Washington, DC.

Ige, A.S., 2016, 'The Church and warfare in the Face of Boko Haram Insurgency in Nigeria: The way forward', Journal of Philosophy, Culture and Religion 19, 26-38.

Isomkwo, A.F. \& Njor, O.E., 2019, 'Ethnic pluralism in Nigeria, adverse effects and the way forward', International Journal of Research and Innovation in Social Science (IJRISS) III(II), 235-238.

Jacob, R.I., 2014, 'Ethnic conflict between the Muslims and Christians in Nigeria: The dilemma of decision-making of the political elites', International Journa of Multicultural and Multireligious Understanding 1(1), 1-11. https://doi. org/10.18415/ijmmu.v1i1.6

Jefford, C.N., 1989, The sayings of Jesus in the teaching of the twelve Apostles. Supplements to Vigiliae Christianae, vol. 11, E.J. Brill, Leiden.

Jefford, C.N., 2015, 'Introduction: Dynamics, methodologies, and progress in Didache studies', in G.R. O'Day (ed.), Early Christianity and its literature, pp. 1-13, SBL Press, Atlanta.

Joseph, Y. \& Rothfuss, R., 2012, 'Threats to religious freedom in Nigeria analysis of a complex scenario', International Journal for Religious Freedom 5(1), 73-85.

Judge, A., 2018, Fundamental need for human sacrifice by Abrahamic religions vital prerequisite for sustainable global civilization?, viewed 18 December 2019, from https://www.laetusinpraesens.org/musings/sacrifice.php.

Juergensmeyer, M., 2001, 'Terror in the name of God', in Current history, pp. 357-361, Philadelphia, PA.

Katulis, B., DeLeon, R. \& Craig, J., 2015, The Plight of Christians in the Middle East, Center for American Progress, Washington, DC.

Klassen, W., 1992, “'Love your enemies": Some reflections on the current status of research', in W.M. Swartley (ed.), The love of enemy and nonretaliation in the New Testament, pp. 1-31, Westminster/John Knox Press, Louisville, KY.
Kloppenborg, J.S., 1979, 'Didache 16:6-8 and Special Matthean Tradition', Zeitschrift für die Neutestamentlice Wissenshcaft 70(1), 54-67.

Koplitz, M.H., 2018, 'Matthew 5:38-42', Sermon Outline, Felton, PA.

Kuhlin, J., n.d., 'Violence against Christians in India', PhD dissertation, Goteborgs Universitet.

Küng, H., 1992, Judaism: The religious situation of our time, transl. J. Bowden, SCM, London.

Küng, H., 2004, Der Islam: Geschichte, Gegenwart, Zukunft, Piper Verlag GmbH, München.

Küng, H., 2005, 'Religion, violence and "holy wars"', International Review of the Red Cross 87(858), 253-268. https://doi.org/10.1017/S1816383100181329

Lee, A.A., 2011, The Baha'i Faith in Africa Establishing a New Religious Movement, 1952-1962, Brill, Leiden.

Luz, U., 2007, Matthew, Fortress, Minneapolis, MN.

MacGregor, K.R., 2008, 'Nonviolence in the ancient Church and Christian Obedience', Themelios 33(1), 16-28.

McNeill, W.H., 1997, 'What we mean by the West', Orbis 41(4), 513-524. https://doi. org/10.1016/S0030-4387(97)90002-8

Mersch, E.S.J., 1933, Le corps mystique du Christ, Études de théologie historique, vol. 2, Museum Lessianum, Leuven.

Milavec, A., 2003, The Didache: Faith, hope, and life of the earliest Christian communities, Paulist Press, New York, NY.

Moore, K.L., 2009, 'Why two swords were enough: Israelite tradition history behind Luke 22:35-38', PhD dissertation, viewed 29 December 2019, from https:// digitalcommons.du.edu/etd/445.

Moule, C.F.D., 1966, The birth of the New Testament, 2nd edn., Adam \& Charles Black, London.

Mueller, J.T., 1934, Christian dogmatics, Concordia Publishing House, St. Louis, MO.

Nel, M., 2018, 'Pentecostal pacifist impulse and the violent God of the Hebrew Bible: A balancing act of hermeneutics', Pentecostal Pacifist Impulse 31(2), 423-441.

Ngele, O.K. \& Peters, P.E., 2019, 'A critical study of Acts 6:1-3 and its implications for political restructuring in Nigeria', HTS TeologieseStudies/Theological Studies 75(4), a5334. https://doi.org/10.4102/hts.v75i4.5334

Ochab, E., 2016, The persecution of Christians in Nigeria, ADF International, Vienna.

O'Loughlin, T., 2011, 'The missionary strategy of the Didache', Transformation 28(2), 77-92. https://doi.org/10.1177/0265378810396298

Oluwaseun, O.A., 2016, 'Religious violence and national security in Nigeria, 1999-2011', International Affairs and Global Strategy 42, 23-31.

Para-Mallam, G., 2019, 'An existential threat to Christianity in Nigeria?', Lausanne Global Analysis 8(4), 1-10.

Peachey, P., 1997, 'Conflicts and Aporias in Abrahamic Monotheism', in P. Peachey, G.F. McLean \& J. Kromkowski (eds.), Abrahamic faiths, ethnicity and ethnic conflicts, pp. 11-18, The Council for Research in Values and Philosophy, Washington, DC

Peters, R., 1995, 'Jihad', in J. Esposito (ed.), The Oxford encyclopedia of the modern Islamic world, pp. 369-373, Oxford University Press, New York, NY.

Pula, M.P., 2015, 'Rethinking the community as temple: Discourse and spatial practice in the community rule (1QS)', PhD dissertation, viewed 29 December 2019, from https://digitalcommons.du.edu/etd/527.

Reid, B.E., 2006, Matthew's nonviolent Jesus and violent parables, Center for Christian Ethics at Baylor University, Waco, TX.

Riesebrodt, M., 2014, Religion in the modern world: Between secularization and resurgence, E.U.I., San Domenico di Fiesole, Italy.

Rordorf, W., 1991, 'Does the Didache contain Jesus tradition independently of the Synoptic Gospels?', in $\mathrm{H}$. Wansbrough (ed.), Jesus and the oral synoptic tradition, pp. 394-423, Sheffield Academic Press, Sheffield.

Spence, C., 1888, The teaching of the twelve Apostles. A translation with notes; and excursus (I. TO IX.) illustrative of the 'teaching', 2nd edn., James Nisbet \& Co, London.

Stonawski, M., Potančoková, M., Cantele, M. \& Skirbekk, V., 2016, 'The changing religious composition of Nigeria: Causes and implications of demographic divergence', Journal of Modern African Studies 54(3), 361-387. https://doi. org/10.1017/S0022278X16000409

Sulaiman, K.O., 2015, 'The concept of Jihad in Islam: An historical perspective', International Journal for Historical Studies 7(1), 111-120. https://doi. org/10.2121/tawarikh.v7i1.627

Sulaiman, K.O., 2016, 'Religious violence in contemporary Nigeria: Implications and options for peace and stability order', Journal for the Study of Religion 29(1), 85-103.

Teehan, J., 2010, In the name of God: The evolutionary origins of religious ethics and violence, John Wiley and Sons, West Sussex, NJ.

Thomas, C., 2019, The Didache: Its origin and significance, viewed 26 December 2019 from https://earlychurch.org.uk>pdf>didache.

Vaughan, O., 2016, Religion and the making of Nigeria, Duke University Press, Durham. Vine, W.E., Unger, M.F. \& White, Jr. W., 1996, Vine's complete expository dictionary, Thomas Nelson, Nashville, TN. 
Volf, M., 2002, 'Christianity and violence', Boardman Lectureship in Christian Ethics vol. 2, viewed 29 December 2019, from http://repository.upenn.edu/boardman/2.

Weaver, D.J., 1992, 'Transforming nonresistance: From Lex Talionis to "Do Not Resist the Evil One"', in W.M. Swartley (ed.), The love of enemy and nonretaliation in the New Testament, pp. 32-71, John Knox Press, Westminster.

Wright, M.C., 1959, The Sociological Imagination. Oxford University Press, New York, NY.
Yake, M.D., 2015, 'Preaching peace and living peacefully in Northern Nigeria: Bridging the gap between theory and practice', International Journal of Humanities and Social Science 5(3), 189-197.

Yin, T., 2013, 'Were Timothy McVeigh and the Unabomber the only white terrorists? Race, religion, and the perception of terrorism', Alabama Civil Rights \&Civil Liberties Law Review 4(1), 56 